University of Nebraska - Lincoln

DigitalCommons@University of Nebraska - Lincoln

USDA National Wildlife Research Center - Staff Publications
U.S. Department of Agriculture: Animal and Plant Health Inspection Service

March 2001

\title{
Daily Activity Budgets and Population Size of American White Pelicans Wintering in South Louisiana and the Delta Region of Mississippi
}

D. Tommy King

USDA/APHIS/WS National Wildlife Research Center, tommy.king@aphis.usda.gov

Scott J. Werner

USDA-APHIS-Wildlife Services, scott.j.werner@aphis.usda.gov

Follow this and additional works at: https://digitalcommons.unl.edu/icwdm_usdanwrc

Part of the Environmental Sciences Commons

King, D. Tommy and Werner, Scott J., "Daily Activity Budgets and Population Size of American White Pelicans Wintering in South Louisiana and the Delta Region of Mississippi" (2001). USDA National Wildlife Research Center - Staff Publications. 552.

https://digitalcommons.unl.edu/icwdm_usdanwrc/552

This Article is brought to you for free and open access by the U.S. Department of Agriculture: Animal and Plant Health Inspection Service at DigitalCommons@University of Nebraska - Lincoln. It has been accepted for inclusion in USDA National Wildlife Research Center - Staff Publications by an authorized administrator of DigitalCommons@University of Nebraska - Lincoln. 


\title{
Daily Activity Budgets and Population Size of American White Pelicans Wintering in South Louisiana and the Delta Region of Mississippi
}

\author{
D. TOMMY KING AND SCOTT J. WERNER
}

\author{
USDA/APHIS/WS, National Wildlife Research Center, P.O. Drawer 6099, MS State University, MS 39762 USA \\ Internet: Tommy.King@aphis.usda.gov
}

\begin{abstract}
Twenty-one American White Pelicans (Pelecanus erythrorhynchos) were captured and fitted with radiotransmitters in south Louisiana and the delta region of Mississippi during the winter and early spring of 1994-1997. The pelicans were monitored to determine their daily activity budgets while using different habitats such as catfish ponds, crawfish ponds, rivers, lakes, and bayous. Pelicans foraging at catfish ponds spent about $4 \%$ of their day foraging and $96 \%$ loafing, while pelicans foraging in other habitats spent about $28 \%$ of their day foraging and $72 \%$ loafing. For an individual bird, the mean number of foraging sessions per day was $2.5( \pm 0.53 \mathrm{SE})$ and the mean length of each foraging session was $66.7 \mathrm{~min}$. $( \pm 8.08 \mathrm{SE})$. Aerial censuses were also conducted to determine the numbers of pelicans in the delta region of Mississippi. Each year the numbers of pelicans wintering in the delta region of Mississippi peaked in February and March, corresponding with spring migration. Pelican numbers reached approximately 4,600 during February and March 1996. Pelicans were observed foraging in larger flocks for shorter periods of time on catfish ponds than in other habitats. Received 27 September 2000, accepted 28 November 2000.
\end{abstract}

Key Words.-Activity budgets, American White Pelican, aquaculture, census, foraging, Louisiana, Mississippi, telemetry.

Waterbirds 24(2): 250-254, 2001

American White Pelicans (Pelecanus erythrorhynchos) in the eastern United States breed primarily in the northern Great Plains and winter in the Lower Mississippi Valley and along the Gulf of Mexico (King 1997; Evans and Knopf 1993; Johnsgard 1993). Most American White Pelican research has been conducted on their breeding grounds in the northern United States and southern Canada (Evans and Knopf 1993; Johnsgard 1993) and little is known about their behavior or the numbers wintering in the southeastern United States.

The Channel Catfish (Ictalurus punctatus) aquaculture industry in the southeastern United States began to expand rapidly in 1985 (Mott and Brunson 1997), increasing production from $86,917 \mathrm{~kg}$ to $255,991 \mathrm{~kg}$ live weight of catfish processed in 1998 (USDA 1999). Of the 15 catfish producing states, Arkansas, Louisiana, and Mississippi increased their pond production from about 24,000 ha in 1987 to over 58,000 ha in 1999 (USDA 1999). A survey of catfish producers by the National Animal Health Monitoring System (NAHMS) indicated that the two primary sources of catfish losses in commercial operations were disease $(45 \%)$ and wildlife (37\%) (NAHMS, United State Department of Agriculture, Animal and Plant Health In- spection Service 1997). Pelicans have been identified as one of the principal hosts in the life cycle of several commercial catfish parasites, especially digenetic trematodes (L. Pote and S. Curran, pers. comm.). American White Pelicans come into conflict with southeastern aquaculture by exploiting this abundant and readily available food source, while potentially transmitting parasites to uncontaminated fish (King 1997).

A more thorough understanding of the daily activity budgets and status of wintering American White Pelicans would lead to more effective methods to manage their impact on the aquaculture industry. The purpose of this study was to determine the activity budgets and numbers of American White Pelicans wintering near southeastern aquaculture facilities.

\section{METHODS}

The study area comprised $16,000 \mathrm{~km}^{2}$ of the Mississippi River alluvial plain (the delta region) in Mississippi and $2,000 \mathrm{~km}^{2}$ of the Atchafalaya River alluvial plain in Louisiana (Fig. 1). American White Pelicans loaf in flooded agricultural fields, on commercial crawfish (Procambarus spp.) pond levees, sand bars, and mud flats of lakes and rivers in Louisiana and Mississippi (King 1997).

From March 1994 to February 1996, twenty-one American White Pelicans were captured in south Louisiana $(\mathrm{N}=10)$ and in the delta region of Mississippi ( $\mathrm{N}$ $=11$ ) with either modified Softcatch ${ }^{\circledR}$ leghold traps or 


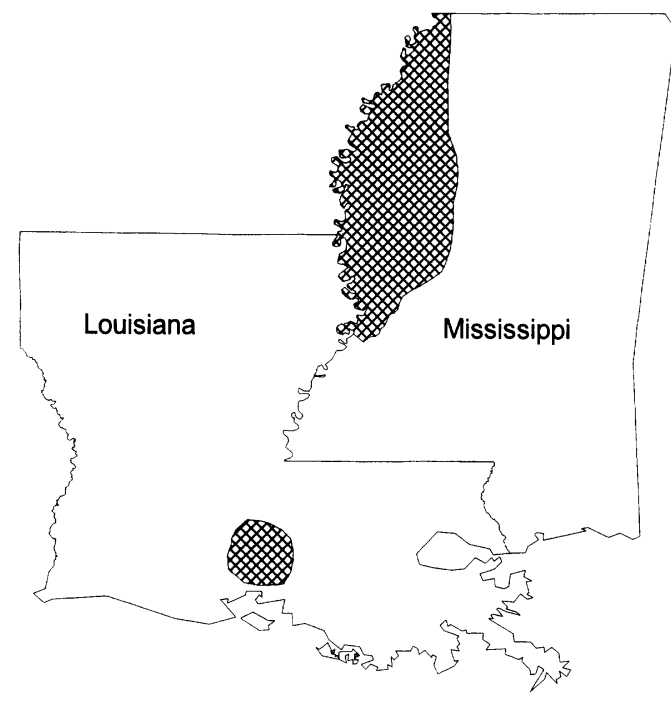

Figure 1. Map of the study areas where transmitterequipped American White Pelicans were tracked from 1994-1997. Shaded areas show ground tracking area in south Louisiana and the delta region of Mississippi.

rocket nets (King et al. 1998). Backpack VHF telemetry transmitters were attached, using methods described by Dunstan (1972). The transmitters weighed $125 \mathrm{~g}$, or approximately $2 \%$ of an adult's body weight (Evans and Knopf 1993, Johnsgard 1993).

After an acclimation period of $48 \mathrm{~h}$, attempts were made to ground track individual pelicans from daylight to dark for one or two successive days. Methods of tracking and locating pelicans were those identified by Mech (1983) and Gilmer et al. (1981). A vehicle with a roofmounted dual three-element yagi antenna system and an R4000 (Advanced Telemetry Systems, Inc.) receiver was used for ground tracking. All activity budget data were obtained by ground tracking. Aerial tracking from a Cessna 172 or 180, using similar equipment, was conducted on several occasions to locate pelicans not previously tracked from the ground.

We calculated the daily activity budgets of transmitter-equipped pelicans as the percentage of ground tracking time that pelicans were engaged in each of three activities; loafing, foraging, and flying. A foraging session was defined as the amount of time a bird spent actively foraging in one bout as determined by visual observation. We determined the mean number of foraging sessions, minutes per foraging session, and time of day of foraging sessions for the different habitats used by pelicans.

Aerial censuses of pelicans were conducted in the delta region of Mississippi during the winters of 19931997. Census transects were established to provide coverage of the entire delta region of Mississippi from an altitude of $500 \mathrm{~m}$. The numbers of pelicans observed were recorded, and aerial photographs of large concentrations of pelicans were taken and individuals were counted from projected photographs. We determined monthly mean counts from November through March. The numbers and locations of pelicans observed foraging were also recorded, as was the percentage of foraging locations per habitat and average size of foraging flocks. We used a Student's t-test $(\mathrm{P}<0.05)$ to compare the mean foraging flock sizes in catfish pond and lake habitats.

\section{RESULTS}

During a four-day period in March 1996, the entire delta region of Mississippi, south Louisiana and the Gulf of Mexico coast from Mobile Bay, Alabama to the Mexico border was flown in an effort to locate all of the transmitter-equipped birds. Only ten birds were located in inaccessible marsh habitat in south Louisiana. It was assumed that the missing birds had left the study area. Attempts to track pelicans at night were unsuccessful because the birds could not be observed to determine if they were foraging or swimming. Therefore, we report only the percent time that pelicans spent foraging during daylight hours $(06.00-17.30 \mathrm{~h})$. Eight birds were ground tracked for more than $7 \mathrm{~h}$ per day for a total of $197 \mathrm{~h}$ over 15 days. All birds flew for less than $1 \%$ of the time tracked.

Pelicans foraging in catfish ponds spent about $4 \%$ of their day foraging and $96 \%$ loafing, while pelicans foraging in other habitats spent about $28 \%$ of their day foraging and $72 \%$ of their day loafing (Fig. 2). In south Louisiana, pelicans were tracked during April and foraged in commercial crawfish ponds when the water level in the ponds was being drawn down to induce the crawfish to burrow and reproduce. The birds foraged exclusively in borrow ditches along the edges of the crawfish ponds because the ponds were too shallow $(<0.1 \mathrm{~m})$ for pelicans to swim. For all habitats combined, the mean

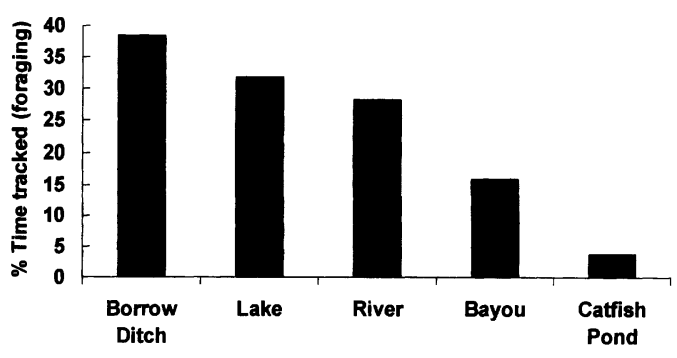

Figure 2. Daily activity budget for transmitter-equipped American White Pelicans foraging in five habitats of south Louisiana and the delta region of Mississippi, 1994-1997. 
Table 1. Mean number of foraging sessions per day of transmitter-equipped American White Pelicans tracked in five habitats during the winter and early spring of 1994-1997 in south Louisiana and the delta region of Mississippi ( $N$ = number of tracking days).

\begin{tabular}{lcccr}
\hline \hline Habitat & $\mathrm{N}$ & Mean & SE & Range \\
\hline Borrow Ditch & 2 & 5.5 & & $3-8$ \\
Mississippi River & 4 & 3.3 & 1.11 & $1-6$ \\
Bayou & 3 & 1.7 & 0.33 & $1-2$ \\
Lake & 4 & 1.5 & 0.29 & $1-2$ \\
Catfish Pond & 2 & 1.0 & & 1 \\
Total & 15 & 2.5 & 0.53 & $1-8$ \\
\hline
\end{tabular}

number of foraging sessions for an individual bird per tracking day was 2.5 ( $\pm 0.53 \mathrm{SE}$ ) (Table 1) and the mean length of individual foraging sessions was $66.7 \mathrm{~min} .( \pm 8.08 \mathrm{SE}$ ) (Table 2). The average number of foraging sessions (Table 1) and the average length of foraging sessions (Table 2) were shorter in commercial catfish ponds than in other habitats. Most pelicans foraged during the morning (06.00-11.00 h) and evening $(14.00-17.30 \mathrm{~h})$ rather than around midday (11.00-14.00 h) in these habitats (Fig. 3).

At least one aerial census was conducted each month from November through late May (or early June) during 1994-95 and 1995-96. During 1993-94 and 1996-97 aerial censuses were conducted irregularly. Pelican numbers in the delta region of Mississippi peaked each year during February or March, reaching about 4,600 birds during 1996 (Fig. 4). There was no significant increase in the number of pelicans in the delta region of Mississippi during February from 1994-1997 $\left(\mathrm{r}_{3}^{2}=0.426 ;\right.$ n.s. $)$.

While conducting aerial censuses in the delta region of Mississippi, most pelicans were observed foraging in lakes, followed by catfish ponds and the Mississippi River (Fig. 5). Peli- cans were not observed foraging in bayous or borrow ditches during these censuses. We observed no differences in flock sizes of pelicans foraging in catfish ponds relative to flocks foraging in lakes $\left(\mathrm{t}_{16.4}=1.43\right.$, n.s.) (Fig. 5).

\section{DISCUSSION}

Since pelicans can fly great distances in relatively short periods (Evans and Knopf 1993; Johnsgard 1993), only eight of 21 birds were tracked for over $7 \mathrm{~h}$. Most transmitterequipped birds apparently left the Mississippi study area within $24 \mathrm{~h}$ of capture and instrumentation. Of the 21 transmitterequipped birds, about 10 were located once a year by aerial telemetry in both study areas. Birds that were located in the coastal marsh habitat of south Louisiana could not be tracked by ground due to logistical constraints (e.g., lack of roads).

All but one of the birds tracked were members of flocks of 500-3,000 pelicans. In most cases the entire group flew, foraged, and loafed as one flock. Overall, pelicans in south Louisiana and the delta region of Mississippi foraged primarily during the morning and afternoon hours, similar to American

Table 2. Mean number of minutes per foraging session of transmitter-equipped American White Pelicans tracked in five habitats during the winter and early spring of 1994-1997 in south Louisiana and the delta region of Mississippi ( $\mathbf{N}=$ number of foraging sessions).

\begin{tabular}{lrrrr}
\hline \hline Habitat & $\mathrm{N}$ & Mean & SE & Range \\
\hline Lake & 6 & 129.5 & 25.5 & $35-210$ \\
Borrow Ditch & 11 & 53.8 & 11.5 & $16-141$ \\
Mississippi River & 13 & 54.6 & 9.0 & $18-119$ \\
Bayou & 5 & 69.4 & 20.8 & $17-143$ \\
Catfish Pond & 2 & 21.0 & & $13-29$ \\
Total & 37 & 66.7 & 8.1 & $13-210$ \\
\hline
\end{tabular}




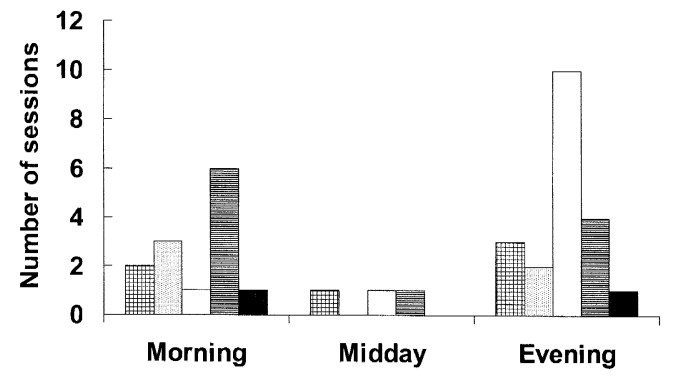

四 Lake $\square$ Bayou $\square$ River E Borrow ditch $\square$ Catfish pond

Figure 3. Number of foraging sessions during three times of day of transmitter-equipped American White Pelicans in south Louisiana and the delta region of Mississippi, $1994-1997$.

White Pelicans breeding in southern Oregon and northeast California (Smith et al. 1984).

Peak numbers of pelicans in the delta region of Mississippi corresponded with the onset of spring migration in February and March, and also with increased complaints of damage from catfish farmers (United States Department of Agriculture, Wildlife Services unpublished data). Although the data show no significant increase in pelican numbers in the delta region of Mississippi from 1993-1997, pelican numbers in this region were variable (Fig. 4). More catfish farmers are reporting pelican problems each year and the birds are becoming more persistent and increasingly difficult to disperse from aquaculture facilities (King 1997; United States Department of Agriculture, Wildlife Services unpublished data).

Subsequent observations of American White Pelicans wintering in south Louisiana and the delta region of Mississippi support

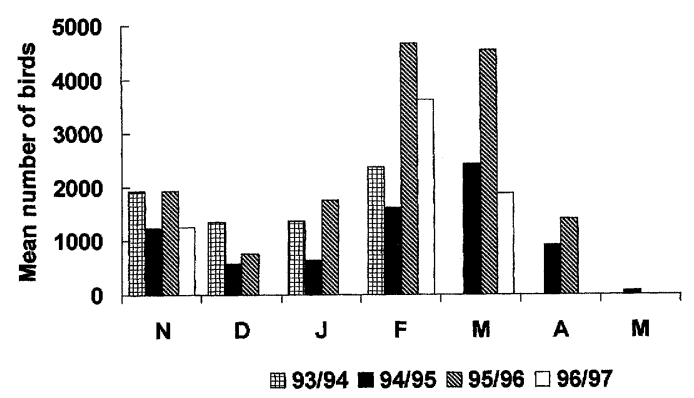

Figure 4. Mean numbers of American White Pelicans observed each month during aerial censuses conducted in the delta region of Mississippi, 1993-1997.
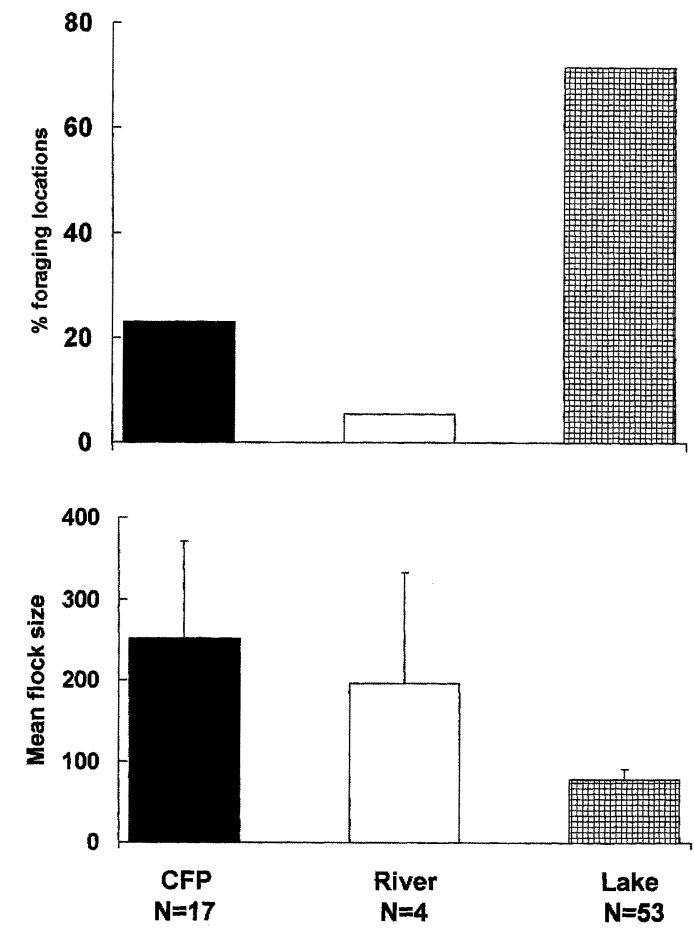

Figure 5. A. Foraging locations and B. flock sizes and SE of American White Pelicans observed on catfish ponds (CFP), rivers, and lakes during aerial censuses conducted in the delta region of Mississippi, 1993-1997.

the activity budgets and general habitat use patterns described in this study. More research however, is needed to determine the extent of utilization and importance of southeastern aquaculture facilities to American White Pelicans, as well as their impact on the industry.

\section{ACKNOWLEDGMENTS}

We would like to thank K. Bruce, T. Carpenter, B. Dorr, R. Gaudé, G. Gaudé, B. Harrel, J. Glahn, D. LeBlanc, P. Mastrangelo, D. Mott, J. Paulson, D. Reinhold, B. Sloan, P. Smith, B. Vermillion, and A. Wilson for assistance with pelican capture and processing. We are grateful to D. Anderson for many helpful suggestions with this study and to B. Dorr and J. Glahn for statistical advice. Thanks also to the landowners who provided access to their property and to pilots T. Michot and B. Nygren. B. Dorr, J. Glahn and M. Tobin provided helpful comments on earlier drafts of this paper.

\section{LiTERATURE CITED}

Dunstan, T. C. 1972. A harness for radio-tagging raptorial birds. Inland Bird Banding News 44: 4-8.

Evans, R. M. and F. L. Knopf. 1993. American White Pelican. The Birds of North America 57: 1-21. 
Gilmer, D. S., L. M. Cowarding, R. L. Duval, L. M. Mechlin, D. W. Shaiffer and V. B. Kuechle. 1981. Procedures for the use of aircraft in wildlife biotelemetry studies. U.S. Fish and Wildlife Service Resource Publication No. 140. Washington, D.C.

Johnsgard, P. A. 1993. Cormorants, darters, and pelicans of the world. Smithsonian Institute Press, Washington, D.C. 445 pp.

King, D. T. 1997. American White Pelicans: the latest avian problem for catfish producers. Proceedings of the Eastern Wildlife Damage Management Conference 7: 31-35.

King, D. T., J. D. Paulson, D. J. LeBlanc and K. Bruce. 1998. Two capture techniques for American White Pelicans and Great Blue Herons. Colonial Waterbirds 21: 258-260.

Mech, L. D. 1983. Handbook of animal radio-tracking. University of Minnesota Press, Minneapolis.

Mott, D. F. and M. W. Brunson. 1997. A historical perspective of catfish production in the southeast in relation to avian predation. Proceedings Eastern Wildlife Damage Management Conference 7: 23-30.

National Animal Health Monitoring System, United States Department of Agriculture, Animal and Plant Health Inspection Service. 1997. Catfish 97: Reference of 1996 catfish health and production practices. Centers for Epidemiology and Animal Health, USDA: APHIS/VS, attention National Animal Health Monitoring System. 555 South Howes, Ft. Collins, CO 80521.

Smith, M. T., T. Steinbach and G. Pampush. 1984. Distribution, foraging relationships and colony dynamics of the American White Pelican (Pelecanus erythrorhynchos) in southern Oregon and northeastern California. Natural Conservation, Portland, OR.

U. S. Department of Agriculture. 1999. Catfish Production. National Agricultural Statistics Service. Washington, D.C. 